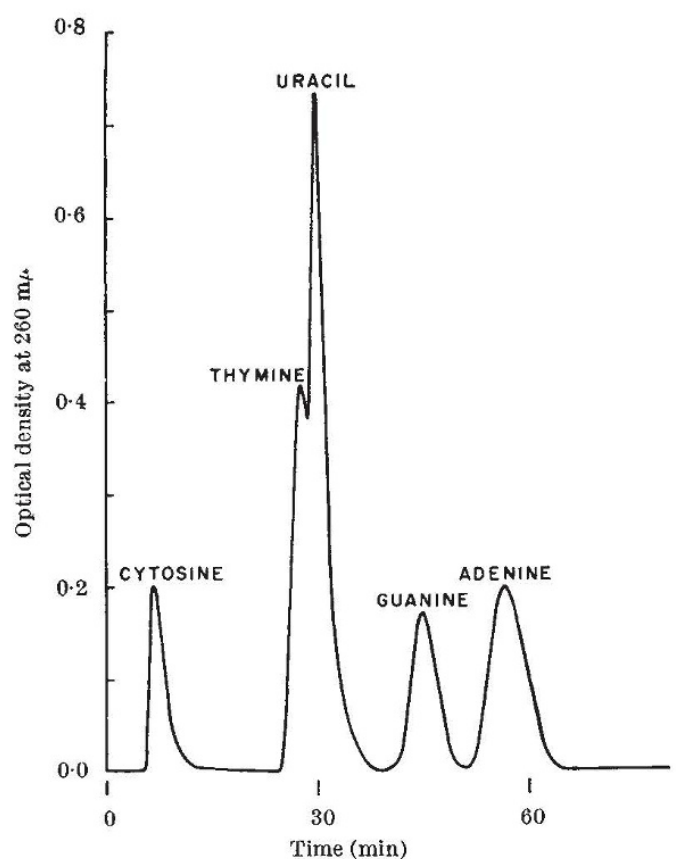

Fig. 3. Accelerated separation of the five major nucleic acid bases

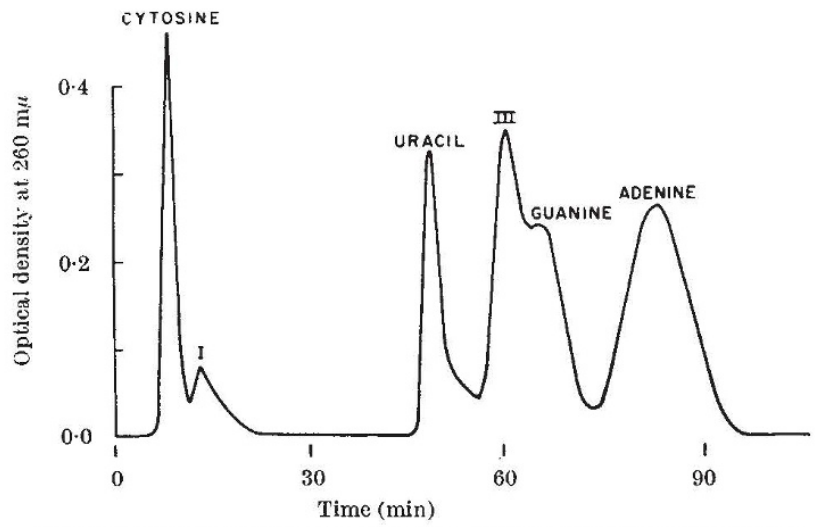

Fig. 4 (a). Bases recovered after 60 min concentrated formic acid hydrolysis of RNA at $175^{\circ} \mathrm{C}$

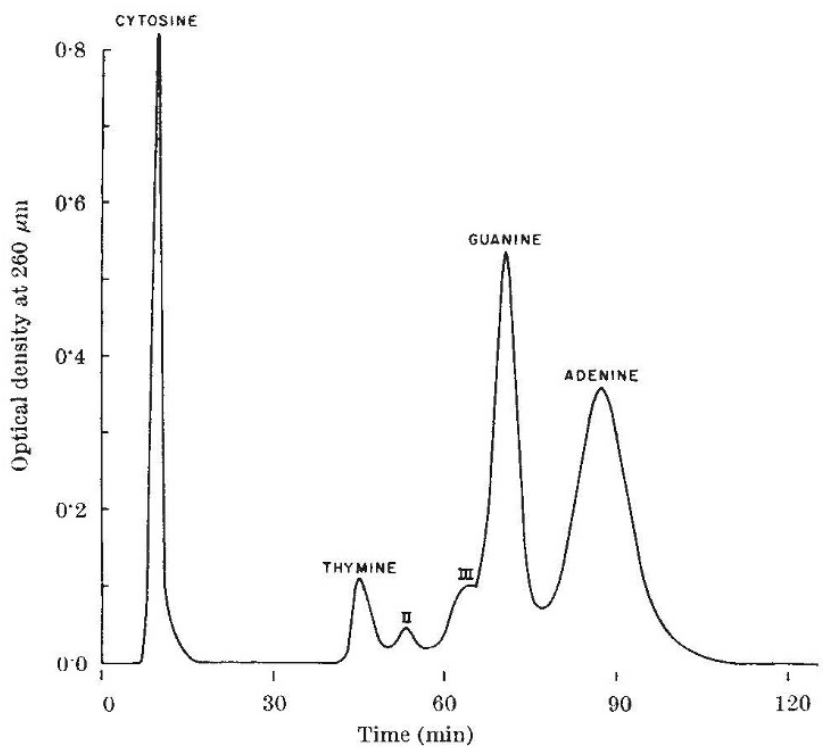

Fig. 4 (b). Bases recovered after 60 min concentrated formic acid hydroJysis of DNA at $175^{\circ}$ C base at the $10^{-10}$ molar level. The wide application of this technique to biochemistry and related sciences is obvious.

The work was supported by research grants from the American Chemical Society and the National Aeronautics and Space Administration.

Department of Chemistry and Geology,

STEVE P. KELEMEN EGON T. DEgENS

The Woods Hole Oceanographic Institution, Woods Hole, Massachusetts.

' Cohn, W. E., Science, 109, 377 (1949). Farmer, T. H., J. Chromatog., 16, 264 (1964).

Bendich, A., et al., J. Amer. Chem. Soc., 80, 3949 (1958). Skidmore, W. D. Main, R. K., and Cole, L. J., Biochim. Biophys. Acta, 76, 534 (1963).

${ }^{3}$ Bauer, R. D., and Martin, K. D., J. Chromatog., 16, 519 (1964).

'Veder, H. A., and Pascha, C. N., J. Chromatog., 13, 408 (1964).

\section{Chemical Nature of the Pigment Spots of Enoplus communis}

Aт the anterior end of the free-living marine nematode Enoplus communis are situated two pigment spots, dark red-brown in life. Their superficial appearance is very reminiscent of eye-spots. Schultz ${ }^{1}$ suggested that these pigment spots were excretory granules and were not in any way associated with photoreception.

Unlike the eye-spots of some marine nematodes, there is no lens structure or well-defined perimeter. The pigment is localized in two lateral pockets inside the oesophageal tissue, and having posterior to the pigment spots diffuse areas of granular pigment which extend back through the oesophageal tissue.

In an attempt to characterize the pigment, a number of solvolysis experiments were carried out, and specific bleaching reagents used. The pigments were fixed in formalin and were found to be readily soluble in concentrated sulphuric acid; they were, however, wholly insoluble in concentrated hydrochloric acid. The pigments disappeared in normal sodium and potassium hydroxides in a few minutes. They were quite unchanged in such organic solvents as diethyl-ether, chloroform, benzene, acetone and xylene. They did not dissolve in ethylene chlorohydrin, but this is only specific after separation from the protein component ${ }^{2}$.

After dissolving the spots in concentrated sulphuric acid, there was a partial return of the colour on diluting with water ${ }^{3}$.

Strong bleaching was found in concentrated and 50 per cent nitric acid and weak bleaching was recorded with solutions of hydrogen peroxide ( 6 per cent, w/v), potassium dichromate $(2.5$ per cent, w/v), and potassium permanganate ( 1 per cent, $\mathrm{w} / \mathrm{v})^{4,5}$.

These results, together with the dark brown colour and granular consistency, strongly suggest that the "eye-spot" is melanin, and is therefore unlikely to be involved directly in photosensitivity.

N. A. Croli

Ashurst Lodge,

Imperial College of Science and 'Technology, University of London.

${ }^{1}$ Schultz, E., Zool. Anzeit., 85, 241 (1931).

${ }^{2}$ Lea, A. J., Nature, 156, 478 (1945).

${ }^{3}$ Anderson, C. G., An Introduction to Bacteriological Chemistry (William Wood and Co., Baltimore, 1938).

- Fox, D. L., Animal Biochromes and Structural Colours (Cambridge University Press, 1953).

${ }^{5}$ Pearse, A. G. E., Histochemistry (Churchill, London, 1961).

\section{Occurrence of D-Lysergic Acid and 6-Methyl- ergol-8-ene-8-carboxylic Acid in Cultures of Claviceps purpurea}

Over the past few years we have been examining the composition of ergot alkaloids produced in vitro by strains of Claviceps purpurea isolated from sclerotia growing on grasses in England. It was noted that exhaustive chloroform extraction of culture filtrates adjusted to $p \mathrm{H} 8 \cdot 5$ 